\title{
Alloying by Magnesium: A Route How to Eliminate the Amount of Ti 2 Ni Phase in Ni-Ti Alloy
}

Andrea Školáková, Pavel Salvetr, Pavel Novák

University of Chemistry and Technology in Prague, Department of Metals and Corrosion Engineering, Technická 5, 166 28 Prague 6, Czech Republic, E-mail: skolakoa@vscht.cz,salvetrp@vscht.cz, panovak@vscht.cz

This article offers completely new results in the research of NiTi alloys produced by Self-propagating High-temperature Synthesis (SHS). There is investigated the effect of addition of magnesium on the microstructure, phase composition and especially, the amount of undesirable $\mathrm{Ti}_{2} \mathrm{Ni}$ phase. This phase is unwanted in NiTi alloy because of its brittleness. Moreover, this one is stabilized by oxygen and forms during SHS process. Selected preparation method is considered as an alternative to the melting metallurgy, which produced products with poor homogeneity and purity. For this reason, SHS process has been studied intensely and many researchers have tried to eliminate secondary phases unsuccessfully. Our research showed that alloying by element with high affinity to oxygen causes disappearance of $\mathrm{Ti}_{2} \mathrm{Ni}$ phase.

Keywords: $\mathrm{Ti}_{2} \mathrm{Ni}$ phase, Self-propagating High-temperature Synthesis, Ni-Ti-Mg alloy

\section{Acknowledgement}

This research was financially supported by Czech Science Foundation, project P108/12/G043 and by MSMT number 20-SVV/2017.

\section{References}

[1] OTSUKA, K., REN, X. (2005). Physical metallurgy of Ti-Ni based shape memory alloys. In: Progress in Materials Science, Vol. 50, No. 5, pp. 511 - 678. Elsevier. Netherlands.

[2] TAY, B. Y., GOH, C. W., GU, Y. W., LIM, C. S., YONG, M. S., HO, M. K., MYINT, M. H. (2008). Porous NiTi fabricated by self-propagating high-temperature synthesis of elemental powders. In: Journal of Materials Processing Technology, Vol. 202, No. 1 - 3, pp. 359 - 364. Elsevier. Netherlands.

[3] NAYAN, N., SAIKRISHNA, C.N., RAMAIAH, K.V., BHAUMIK, S.K., NAIR, K.S., MITTAL, M.C. (2007). Vacuum induction melting of NiTi shape memory alloys in graphite crucible. In: Materials Science and Engineering: $A$, Vol. 465, No. 1-2, pp. 44-48. Elsevier. Netherlands.

[4] SADRNEZHAD, S.K, RAZ, S.B. (2005). Interaction between refractory crucible materials and the melted NiTi shape-memory alloy. In: Metallurgical and Materials Transactions B, Vol. 36, No. 3, pp. 395-403. Springer. Germany

[5] YANG, Y. F., WANG, H. Y., ZHAO, R. Y., LIANG, Y. H., ZHAN, L., JIANG, Q. C. (2008). Effects of C particle size on the ignition and combustion characteristics of the SHS reaction in the $20 \mathrm{wt}$. \% Ni-Ti-C system. In: Journal of Alloys and Compounds, Vol. 460, No. $1-2$. Elsevier. Netherlands.

[6] BASSANI, P., BASSANI, E., TUISII, A., GIULIANI, P., ZANOTTI, C. (2014). Nonequiatmic NiTi alloy produced by self propagating high temperature synthesis. In: journal of Materials Engineering and Performance, Vol. 23, No. 7, pp. 2373 - 2378. Springer. Germany.

[7] NOVÁK, P., POKORNÝ, P., VOJTĚCH, V., KNAISLOVÁ, A., ŠKOLÁKOVÁ, A., ČAPEK, J., KARLÍK, M., KOPEČEK, J. (2015). Formation of Ni - Ti intermetallics during reactive sintering at $500-650{ }^{\circ} \mathrm{C}$. In: Materials Chemistry and Physics, Vol. 155, pp. 113 - 121. Elsevier. Netherlands.

[8] NOVÁK, P., ŠKOlÁKOVÁ, A., VOJTĚCH, V., KNAISlOVÁ, A., POKORNÝ, P., MORAVEC, H., KOPEČEK, J., KARLÍK, M., KUBATÍK, T. F. (2014). Applications of microscopy and x-ray diffraction in optimization of the production of NiTi alloy by powder metallurgy. In: Manufacturing Technology. Vol. 14, No. 3, pp. 387 - 392. UJP. Czech Republic.

[9] SALVETR, P., NOVÁK, P., MORAVEC, H. (2015). Ni-Ti alloys produced by powder metallurgy. In: Manufacturing technology, Vol. 15, No. 4, pp. 689 - 694. UJP. Czech Republic.

[10] ŠKOLÁKOVÁ, A., NOVÁK, P., SALVETR, P. (2016). Influence of elements with high affinity to oxygen on microstructure and phase composition of Ni-Ti alloy. In: Manufacturing technology, Vol. 16, No. 4, pp. 808 - 814. UJP. Czech Republic. 
[11] ŠKOLÁKOVÁ, A., NOVÁK, P., SALVETR, P. (2016). Thermal analysis of Ni-Ti-X alloys prepared by Selfpropagating High-temperature Synthesis. In: Manufacturing technology, Vol. 16, No. 5, pp. 1146 - 1150 . UJP. Czech Republic.

[12] DU, J., WEN, B., MELNIK, R., KAWAZOE, Y. (2014). First-principles studies on structural, mechanical, thermodynamic and electronic properties of Ni-Zr intermetallic compounds. In: Intermetallics, Vol. 54, pp. 110 - 119. Elsevier. Netherlands

[13] NEVITT, M. V. (1960). Stabilization of certain amount $\mathrm{Ti}_{2} \mathrm{Ni}$-type phases by oxygen. In: Transactions of the Metallurgical Society of AIME, Vol. 218, pp. 327 - 331. American Institute of Mining, Metallurgical and Petroleum Engineers. USA.

[14] MASSALSKI, T. B. (1990). Binary Alloy Phase Diagrams, ASM, Materials Park

[15] SALVETR, P., DANEY, B., NOVÁK, P. (2016). Comparison of Ni-Ti-Si alloy prepared by various powder metallurgy routes. In: Manufacturing technology, Vol. 16, No. 5, pp. 1136 - 1140. UJP. Czech Republic.

[16] KRISTIANOVÁ, E., NOVÁK, P. (2016). Composite materials NiTi-Ti, Ni. In: Manufacturing Technology, Vol. 16, No. 5, pp. 961-965. UJP. Czech Republic.

[17] DU, J., WEN, B., MELNIK, R., KAWAZOE, Y. (2014). First-principles studies on structural, mechanical, thermodynamic and electronic properties of Ni-Zr intermetallic compounds. In: Intermetallics, Vol. 54, pp. 110 - 119. Elsevier. Netherlands. 